\title{
EFECTO DE LA FERTILIZACIÓN CON Ca, Mg, N, P Y S SOBRE LOS COMPONENTES DE RENDIMIENTO DE TRIGO EN EL DEPARTAMENTO LAS COLONIAS, SANTA FE
}

\author{
ImVinkelried, H.O. ${ }^{1}$; Dellaferrera, I. M. ${ }^{1,2}$; HeRmann, O.M. ${ }^{1}$; \\ PIETROBÓN, M. ${ }^{1} ;$ ZEN, O. ${ }^{1}$ \& MAUMARY, R. ${ }^{1}$
}

\begin{abstract}
RESUMEN
El logro del rendimiento potencial del cultivo esta condicionado por el manejo, donde la nutrición del mismo juega un rol esencial. El objetivo del presente trabajo consistió en evaluar el efecto del agregado de un compuesto cálcico-magnésico-azufrado (MRD 2500®), en combinación con $\mathrm{N}$ y $\mathrm{P}$, sobre los componentes del rendimiento y la productividad del cultivo de trigo. El ensayo se realizó durante la campaña 2010 en la localidad de Esperanza (Santa Fe). Se realizaron 4 tratamientos que consistieron en: (i) $\mathrm{MRD}+\mathrm{N}+\mathrm{P}$, (ii) $\mathrm{MRD}+\mathrm{N}$, (iii) $\mathrm{N}$ y (iv) Testigo. El tratamiento MRD+N+P logró aproximadamente un $20 \%$ de incremento en la productividad y producción. Se pudo demostrar el efecto positivo de la combinación de los macronutrientes evaluados.
\end{abstract}

Palabras clave: producción, productividad, tasa de crecimiento del cultivo, trigo.

\section{SUMMARY}

\section{Effect of $\mathrm{Ca}, \mathrm{Mg}, \mathrm{N}, \mathrm{P}$ and $\mathrm{S}$ fertilization on wheat yield components in Las Colonias department, Santa Fe.}

Fertilization management is the most important trait for the full expression of crop yield potential. The aim of this work was to evaluate the effect of the addition of a calcium-magnesium-sulfur substance (MRD $2500 \AA$ ) in combination with $\mathrm{N}$ and $\mathrm{P}$ on yield components and productivity of wheat crop. The experiment was conducted during 2010 season in Esperanza (Santa Fe). The four treatments were: (i) $\mathrm{MRD}+\mathrm{N}+\mathrm{P}$, (ii) $\mathrm{MRD}+\mathrm{N}$, (iii) $\mathrm{N}$ and (iv) Control. The $\mathrm{MRD}+\mathrm{N}+\mathrm{P}$ treatment achieved approximately a $20 \%$ increase in productivity and production. Could be demonstrated the positive effect of the combination of macronutrients evaluated.

Key words: production, productivity, crop growth rate, wheat.

1.- Docente-investigador. Facultad de Ciencias Agrarias, Universidad Nacional del Litoral. Kreder 2805 (3080) Esperanza, provincia de Santa Fe - Telefax: (03496) 426400, interno 365.

2.- IAL - CONICET.

Manuscrito recibido el 16 de abril de 2013 y aceptado para su publicación el 19 de noviembre de 2013. 